\title{
Karyosystematic and karyotype evolution of Panstrongylus lutzi (Neiva \& Pinto, 1923) (Hemiptera, Triatominae)
}

\author{
K. C. C. Alevi ${ }^{a}$, C. H. L. Imperador ${ }^{a}$, E. O. L. Fonseca ${ }^{b}$, C. G. S. Santos ${ }^{b}$, \\ M. T. V. Azeredo-Oliveira ${ }^{a}$,J. A. Rosa ${ }^{c}$ and J. Oliveira ${ }^{c}$
}

a'Laboratório de Biologia Celular, Departamento de Biologia, Instituto de Biociências, Letras e Ciências Exatas - IBILCE, Universidade Estadual Paulista "Júlio de Mesquita Filho" - UNESP, Rua Cristóvão Colombo, 2265, Jardim Nazareth, CEP 15054-000, São José do Rio Preto, SP, Brazil

'Laboratório de Entomologia, Laboratório Central de Saúde Pública Professor Gonçalo Moniz Central - LACEN, Rua Waldemar Falcão, 123, Horto Florestal, CEP 40295-010, Salvador, BA, Brazil

'Laboratório de Parasitologia, Departamento de Ciências Biológicas, Faculdade de Ciências Farmacêuticas - FCFAR, Universidade Estadual Paulista "Júlio de Mesquita Filho" - UNESP, Rodovia Araraquara-Jaú, Km 1,

CEP 14801-902, Araraquara, SP, Brazil

*e-mail: kaiochaboli@hotmail.com

Received: July 11, 2016 - Accepted: September 17, 2016 - Distributed: February 28, 2018

(With 2 figures)

\section{Scientific Note}

Currently, there are 153 species of triatomines, distributed in 18 genera, being all species considered as potential vector of Chagas disease (Alevi et al., 2016; Rosa et al., 2017). The genus Panstrongylus Berg, 1879 is composed of 15 species, being 14 species alive and one fossil. Cytogenetic analyses in Panstrongylus were initiated in 1950 with the karyotype description of P. megistus (Schreiber and Pellegrino, 1950). Until now the number of chromosomes in seven species of Panstrongylus was described, of which with the exception of $P$. megistus which has 21 chromosomes $\left(2 \mathrm{n}=18 \mathrm{~A}+\mathrm{X}_{1} \mathrm{X}_{2} \mathrm{Y}\right)$, all other species analyzed (P. chinai, P. geniculatus, P. howardi, $P$. lignarius, $P$. rufotuberculatus and $P$. tupynambai) have 23 chromosomes $\left(2 \mathrm{n}=20 \mathrm{~A}+\mathrm{X}_{1} \mathrm{X}_{2} \mathrm{Y}\right)$ (Schreiber and Pellegrino, 1950; Pérez et al., 2002; Panzera et al., 2010).

Based on homogeneity of the number of chromosomes $(2 \mathrm{n}=23)$ and sex determination system $\left(\mathrm{X}_{1} \mathrm{X}_{2} \mathrm{Y}\right)$ of the genus Panstrongylus, Perez et al. (2002) suggested that these triatomines were possibly originated from ancestors of North America, because all species of South America [except Triatoma melanocephala $(2 \mathrm{n}=24), T$. vitticeps $(2 \mathrm{n}=24)$ and T. tibiamaculata $(2 \mathrm{n}=23)$ (Alevi et al., 2012)] have $2 \mathrm{n}=22$ chromosomes and XY sex determination system (Panzera et al., 2010). These results were recently confirmed based on molecular analysis (Justi et al., 2014).

Thus, in order to assist in the chromosomal and evolutionary knowledge of the genus Panstrongylus and Triatominae subfamily, this study aimed to analyze the karyotype of $P$. lutzi and compare with karyotypes already described for other species of the triatomines.

One adult male of $P$. lutzi was collected in wild environment in the State of Bahia, Brazil (S 12.41'407 “, W 039.26'210" and elevation 167 meters). We justify that only one specimen was analyzed by the absence of P. lutzi in Brazilian insectaries and mainly by the difficulty of collecting and maintaining of these species in the laboratory, since for cytogenetic analyzes the insects might not be killed or fixed in alcohol (as occurs for molecular analysis). The seminiferous tubules of adult males were torn and fixed to a cover slip. They then underwent the cytogenetic technique of Lacto-acetic orcein (De Vaio et al., 1985 with modifications according to Alevi et al., 2012) and analyzed using a Jenaval light microscope (Zeiss). For the characterization of the karyotype were analyzed 50 mitotic metaphases (I and II).

As well as was observed recently by Santos et al. (2016), $P$. lutzi presented a different karyotype of all species of the genus Panstrongylus, namely, $2 \mathrm{n}=24\left(20 \mathrm{~A}+\mathrm{X}_{1} \mathrm{X}_{2} \mathrm{X}_{3} \mathrm{Y}\right)$, being the $\mathrm{Y}$ sex chromosome heteropycnotic (Figure 1). This number of chromosomes is very peculiar because it was described to only three other species in subfamily Triatominae: T. melanocephala (Alevi et al., 2012), T. vitticeps (Schreiber and Pellegrino, 1950) and T. eratyrusiformis (Ueshima, 1966).

Starting from the principle that the ancestral karyotype of Panstrongylus is $2 \mathrm{n}=23$ (Perez et al., 2002), during karyotype evolution of $P$. megistus and $P$. lutzi occurred simploidy (fusion) of a pair of autosomes (Perez et al., 2002) and agmatoploidy (fission) of X sex chromosome, respectively (Figure 2). The number of chromosomes of the $P$. megistus $(2 \mathrm{n}=21)$ and $P$. lutzi $(2 \mathrm{n}=24)$ can be used as a taxonomic tool to differentiate this species from all species of genus Panstrongylus $(2 \mathrm{n}=23)$, as well as allows distinguishing them from other 85 species of Triatominae subfamily that presents 22 ( 55 species) or 23 ( 30 species) chromosomes (Alevi et al., 2016; Bardella et al., 2016; Mendonça et al., 2016; Rosa et al., 2017).

Jurberg et al. (2001) based on chromatic and morphological analysis of only one specimen collected in Bahia described P. sherlocki as sister species of $P$. lutzi. However, Garcia et al. (2005) when analyze P. lutzi coming from the municipalities of Sobral (Bahia) and 


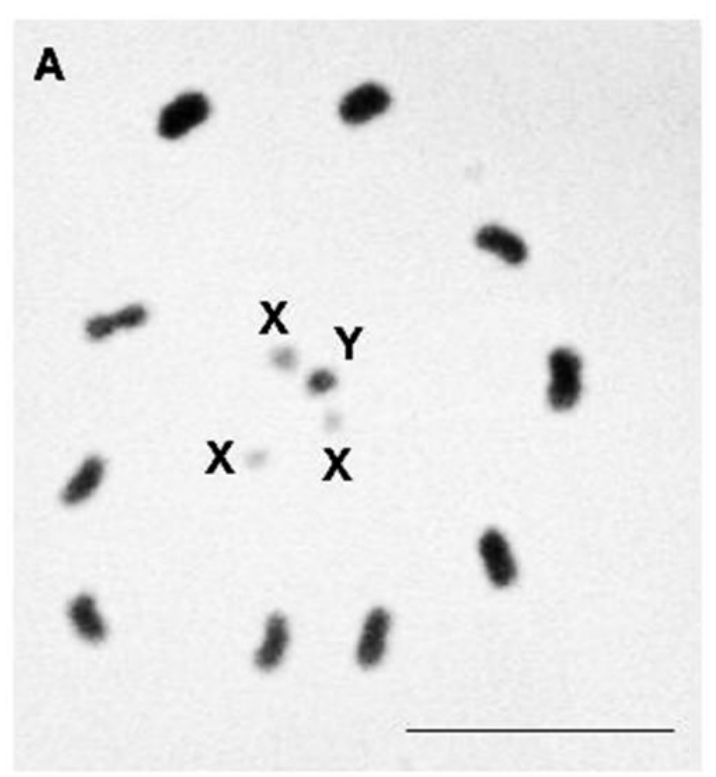

Figure 1. Karyotype of the Panstrongylus lutzi. Note $2 \mathrm{n}=24\left(20 \mathrm{~A}+\mathrm{X}_{1} \mathrm{X}_{2} \mathrm{X}_{3} \mathrm{Y}\right)$ chromosomes. $\mathrm{X}: \mathrm{X}$ sex chromosome; Y: Y sex chromosome. Bar: $10 \mu \mathrm{m}$.

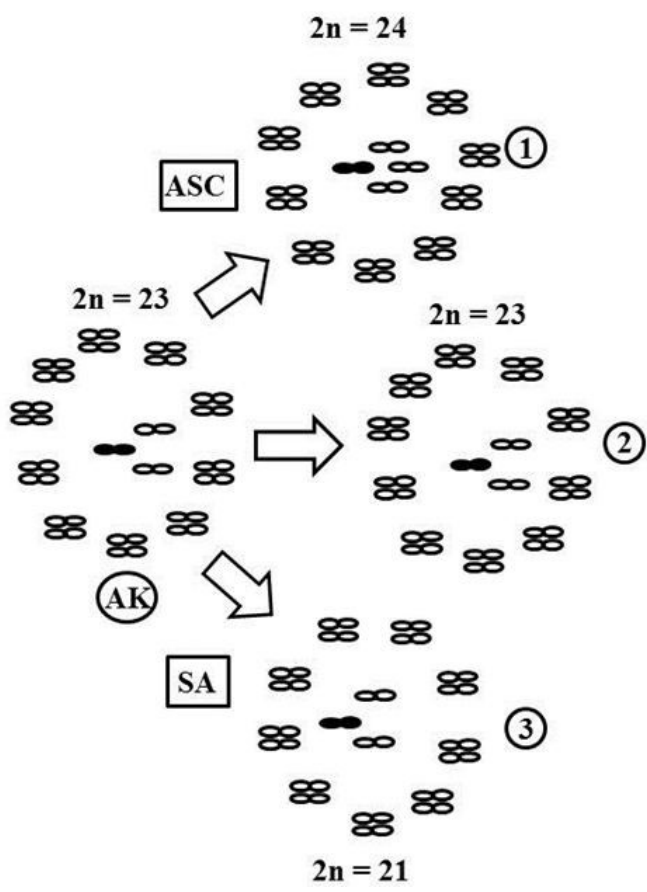

Figure 2. Karyotype evolution in the genus Panstrongylus. Note that from ancestral karyotype $2 \mathrm{n}=23$, occurred three evolutionary events during the speciation of these vectors: (1) agmatoploidy in $\mathrm{X}$ sex chromosome, resulting in karyotype $2 \mathrm{n}=24$ (P. lutzi); (2) absence of events that alter the karyotype numerically, keeping the same ancestor number $2 \mathrm{n}=23$ (P. chinai, $P$. geniculatus, $P$. howardi, $P$. lignarius, $P$. rufotuberculatus and $P$. tupynambai); (3) simploidy in a pair of autosomes, resulting in karyotype $2 \mathrm{n}=21$ (P. megistus). AK: ancestral karyotype; ASC: agmatoploidy in sex chromosome; SA: simploidy in autosomes.
Crateús (Ceará) observed high variability in morphological and morphometric characteristics and they classified the morphotypes that had the characteristics of $P$. sherlocki as $P$. lutzi. On that basis, $P$. sherlocki became considered as synonymous with P. lutzi (Schofield and Galvão, 2009). However, due to peculiarity observed in the karyotype of $P$. lutzi, we suggest that new karyotypic studies should be conducted on specimens initially classified as $P$. sherlocki by Jurberg et al. (2001), because if a different karyotype of $2 n=24$ is observed, the number of chromosomes would support the revalidation of the species.

Thus, this paper describes the number of chromosomes of P. lutzi $\left[2 \mathrm{n}=24\left(20 \mathrm{~A}+\mathrm{X}_{1} \mathrm{X}_{2} \mathrm{X}_{3} \mathrm{Y}\right)\right]$, suggests that karyotype arose from one agmatoploidy event of the $\mathrm{X}$ sex chromosome and mainly apply these data as taxonomic tool to differentiate this vector of other species of the genus Panstrongylus, as well as subfamily Triatominae.

\section{Acknowledgements}

The study was supported by Fundação de Amparo à Pesquisa do Estado de São Paulo (process numbers 2013/197640, Brazil) and Conselho Nacional de Desenvolvimento Científico e Tecnológico (CNPq, Brazil).

\section{References}

ALEVI, K.C.C., MENDONÇA, P.P., PEREIRA, N.P., ROSA, J.A. and AZEREDO-OLIVEIRA, M.T.V., 2012. Karyotype of Triatoma melanocephala Neiva and Pinto (1923). Does this species fit in the Brasiliensis subcomplex? Infection, Genetics and Evolution, vol. 12, no. 08, pp. 1652-1653. PMid:22760157. http://dx.doi.org/10.1016/j.meegid.2012.06.011.

ALEVI, K.C.C., MOREIRA, F.F.F., JURBERG, J. and AZEREDOOLIVEIRA, M.T.V., 2016. Description of diploid chromosome set of Triatoma pintodiasi (Hemiptera, Triatominae). Genetics and Molecular Research, vol. 15, no. 2, pp. 1-9.

BARDELLA, V.B., PITA, S., VANZELA, A.L.L., GALVÃO, C. and PANZERA, F., 2016. Heterochromatin base pair composition and diversification in holocentric chromosomes of kissing bugs (Hemiptera, Reduviidae). Memórias do Instituto Oswaldo Cruz, vol. 111, no. 10, pp. 614-624. PMid:27759763. http://dx.doi. org/10.1590/0074-02760160044.

DE VAIO, E.S., GRUCCI, B., CASTAGNINO, A.M., FRANCA, M.E. and MARTINEZ, M.E., 1985. Meiotic differences between three triatomine species (Hemiptera:Reduviidae). Genetica, vol. 67, no. 3, pp. 185-191. http://dx.doi.org/10.1007/BF02424489.

GARCIA, M.H.H.M., SOUZA, L., SOUZA, R.C.M., PAULA, A.S., BORGES, E.C., BARBOSA, S.E., SCHOFFIELD, C.J. and DIOTAIUTI, L., 2005. Occurrence and variability of Panstrongylus lutzi in the state of Ceará, Brazil. Revista da Sociedade Brasileira de Medicina Tropical, vol. 38, no. 5, pp. 410-415. PMid:16172758. http://dx.doi.org/10.1590/S0037-86822005000500010.

JURBERG, J., CARCAVALLO, R.U. and LENT, H., 2001. Panstrongylus sherlocki sp.n. do estado da bahia, Brasil (hemiptera, reduviidae, triatominae). Entomología y Vectores, vol. 8, no. 2, pp. 261-274.

JUSTI, S.A., RUSSO, C.A.M., MALLET, J.R.S., OBARA, M.T. and GALVÃO, C., 2014. Molecular phylogeny of Triatomini 
(Hemiptera: Reduviidae: Triatominae). Parasites \& Vectors, vol. 7, no. 149, pp. 1-12.

MENDONÇA, V.J., ALEVI, K.C.C., PINOTTI, H., GURGELGONGALVES, R., PITA, S., GUERRA, A.L., PANZERA, F., ARAÚJO, R.F., AZEREDO-OLIVEIRA, M.T.V. and ROSA, J.A., 2016. Revalidation of Triatoma bahiensis Sherlock \& Serafim, 1967 (Hemiptera: Reduviidae) and phylogeny of the T. brasiliensis species. Zootaxa, vol. 4107, no. 2, pp. 239-254. PMid:27394816. http://dx.doi.org/10.11646/zootaxa.4107.2.6.

PANZERA, F., PÉREZ, R., PANZERA, Y., FERRANDIS, I., FERREIRO, M.J. and CALLEROS, L., 2010. Cytogenetics and genome evolution in the subfamily Triatominae (Hemiptera, Reduviidae). Cytogenetics and Genome Research, vol. 128, no. 1-3, pp. 77-87.

PÉREZ, R., HERNÁNDEZ, M., CARACCIO, M., ROSE, V., VALENTE, A., VALENTE, V., MORENO, J., ANGULO, V., SANDOVAL, M., ROLDÁN, J., VARGAS, F., WOLFF, M. and PANZERA, F., 2002. Chromosomal evolution trends of the genus Panstrongylus (Hemiptera, Reduviidae), vectors of Chagas Disease. Infection, Genetics and Evolution, vol. 2, no. 01, pp. 47-56. PMid:12798000. http://dx.doi.org/10.1016/S15671348(02)00063-1.
ROSA, J.A., JUSTINO, H.H.G., NASCIMENTO, J.D., MENDONÇA, V.J., ROCHA, C.S., CARVALHO, D.B., FALCONE, R., AZEREDOOLIVEIRA, M.T.V., ALEVI, K.C.C. and OLIVEIRA, J., 2017. A new species of Rhodnius from Brazil (Hemiptera, Reduviidae, Triatominae). ZooKeys. In press.

SANTOS, S.M., POMPOLO, S.G., GONÇALVES, T.C.M., FREITAS, S.P.C., RANGEL, E.F. and SANTOS-MALLET, J.R.S., 2016. New sex-determination system in the genus Panstrongylus (Hemiptera: Reduviidae) revealed by chromosomal analysis of Panstrongylus lutzi. Parasites \& Vectors, vol. 9, no. 1, pp. 295. PMid:27209318. http://dx.doi.org/10.1186/s13071-016-1574-6.

SCHOFIELD, C.J. and GALVÃO, C., 2009. Classification, evolution, and species groups within the Triatominae. Acta Tropica, vol. 110, no. 2-3, pp. 88-100.

SCHREIBER, G. and PELLEGRINO, J., 1950. Eteropicnosi di autosomi come possible meccanismo di speciazione (Ricerche citologiche su alcuni Emitteri neotropici). Sciencia Genetica, vol. 3, pp. 215-226.

UESHIMA, N., 1966. Cytotaxonomy of the Triatominae (Reduviidae, Hemiptera). Chromosoma, vol. 18, no. 01, pp. 97-122. http:// dx.doi.org/10.1007/BF00326447. 